\title{
Lumbung Desa in Java: A Credit Institution, Poverty Management, and Financial Problem Solving for Villagers During the Colonial Period
}

\author{
Haryono Rinardi, Yety Rochwulaningsih, Titiek Suliyati, Sutejo K. Widodo \\ Diponegoro University \\ E-mail: haryonorinardi@hotmail.com
}

\begin{abstract}
This paper aims to examine the existence and development of Lumbung Desa or village rice barns as a credit institution during the colonial era. It was expected to be an inspiration and reference to revitalize, design, and develop barns at the village level that contributed significantly to the village welfare at the recent time. Therefore, how and why was Lumbung Desa institution able to develop during the colonial era? How much was its contribution to the village welfare? To examine these questions, the authors used critical historical method and through economical and sociological approach. The result shows that Lumbung Desa was formed and developed by the Dutch to overcome poverty as a strategic issue at the time, especially at village level. The grand design program of Lumbung Desa was to channel loan schemes especially and savings that could be in the form of in cash or rice. It was used to help farmers against the middlemen and moneylenders who were considered as adverse parties for the villagers. Lumbung Desa existed and was managed in many villages of Java during the colonial era. It relied on rural communities with distinctive personal socio-economic relations that brought about both strengths and weaknesses for the institution. However, there were some advantages of Lumbung Desa; first, it provided loans in two types, cash and/ or rice which became major and urgent needs for the villagers; second, its presence in rural areas made farmers become customers and easily access the market; third, its flexibility made it easily transform according to rural community needs.
\end{abstract}

Keywords: village rice barns, credit institution, poverty management, colonial period

\section{INTRODUCTION}

One of the principal problems faced by the Dutch Colonial government in the early twentieth century was poverty that hit most of indigenous communities in Dutch-East Indies. In Java especially, the issue of poverty can be analyzed from various factors. First, it is indicated by the intake of food consumed by indigenous people. According to Boomgaard calculation; the number of consumed calories by villagers in 1880 was much lower than in 1815. Boomgaard calculates that consumed calories in 1880 reached 1698 kilo calories (kcal) per capita compares with $1808 \mathrm{kcal}$ in 1815 and moreover, the difference seems more obvious if all crops are converted to calories. If the issue of "quality" is included in the calculation, then all crops will be multipled to the equivalent of rice and calories consumed, so it can be counted that the indigenous population in 1880 consumed $1562 \mathrm{kcal}$ per year. It was much lower than in 1815 with $1830 \mathrm{kcal}$ (Boomgaard, 2004).

Second, there was a decrease on indigenous people welfare. It is indicated by the number of working hours in productive sectors. According 
to the liberals, working hours increased for indigenous people caused by the implementation of cultivation system was considered as one of the most influencial factors leading to poverty (Elson, 1988). Long working hours indicate the maginitude of the workload of indigenous people. With this fact, their working hours increased during 1880 compared with the previous period. Boomgaard also calculates the average increase of workload per-family farm, ranging from 592 hours in 1815 up to 669 hours in 1880 (Boomgaard, 2004).

Working-hours increase should have been balanced with growth of rate per capita consumption. In the late nineteenth century, consumption level in Java decreased as it has been mentioned earlier. Boomgaard's calculation excluded agricultural sector that could have calculated the average income (generated by agriculture) per family farm. Boomgaard's calculation shows that consumption of rice per household in 1815 amounted to $1,378 \mathrm{~kg}$ of rice, $1,086 \mathrm{~kg}$ in 1840 , and $1,519 \mathrm{~kg}$ in 1880 . It shows that family income in 1880 was much higher than 1815 , both were indicated by rice consumption. If it is reduced with the power of input index, the result becomes $1,344 \mathrm{~kg}$ of rice in 1880 compared with 1,378 kg in 1815 (Boomgaard, 2004). Based on the calculation, the farmer family incomes in 1815 was still higher than in 1880 .

The decrease income (consumption) among the population in Java can be viewed from the decline of food quality. In the end of the ninetheenth century, population in Java began consuming non-rice staples as their main food sources. In that condition, they turned to cassava or yam plant as alternative crops (Dixon, 1979). The government encouraged Javanese people to plant cassava, corn, and beans as alternative crops in addition to rice, especially during the famine (De Vries, 1987).

The colonial government realized the importance of alternative food sources. It was caused by rice price that continued to increase. This sufferred small local farmers. The dilemma was a decrease of welfare in Java. It must be addressed by introducing alternative food sources that can easily grow in almost all or any soil condition without requiring complex treatments. Rice crops need water and a high level of soil fertility with sufficient care. In addition, rice markets responded to variations in rainfall, which is an important factor in rice production, rainfall matters considerably to crop production, particularly rice (van der Eng, 2010). This policy indicates that there was a decline in prosperity among the indigenous population compared with the previous period.

This problem was solved by introducing Ethical Policy in 1901. It included agricultural loan scheme for rural communities (Baudet \& Brugmans, 1987). The government introduced three credit institutions at the village level i.e., Bank Desa (village bank), Lumbung Desa (village barn), Afdelingbank (Knight, 2014). Credit institutions were very important to help farmers because they served as alternative money lending institutions with low initerest rate compared with loan sharks (Kern, 1904). Bank Desa was a unique credit institution. Lumbung Desa adhered two types of transaction formed in cash of money or in rice. It would be easier for villagers to apply for credit and pay. This article reveals the existence and development of Lumbung Desa as a villagelevel credit institution and its contribution for improving the welfare of villagers. The study of Lumbung Desa refers to the study of credit development in Indonesia which is still limited. Several classifications of Lumbung Desa model refer to the credit system classification introduced by de Wolff van Westerrode (1897), a civil servant who lived in Java and much enthusiasm for cooperative belongs to Javanese farmers in the $19^{\text {th }}$ century. He adopted cooperative for farmers from Raiffeisen which was previously developed in Germany since 1849, this idea was applied in his working area at Purwokerto (Henley, 2009; van Zanden \& Marks, 2010). Meanwhile, almost at the same time, Meanwhile, there was other classification of credit system which was running in Java, a Resident of Cirebon J.W. Mesman somewhat modified a credit design that two years before it had been introduced by De Wolff.

Lumbung Desa as one of the microfinance institutions that easily accessible by farmers in rural areas in the midst of credit expansion which was almost dominated by pawnshops and village banks (volksbanken). Therefore, as Zanden and Marks (2010) already predicted, there is one clear 
doubt that clear institutions related to small-scale agriculture such as Lumbung Desa and village banks were predicted to face difficulties in carrying out its mission (van Zanden \& Marks, 2010).

Therefore, this paper aims to answer some questions; first, the main cause underlying the establishment of Lumbung Desa; second, management of organization including the funding of Lumbung Desa; and third, the advantages of Lumbung Desa as a village credit institution.

Discussion of Lumbung Desa's development as microcredit institution during 1905-1940 will be outlined below. Major analyze will be focused on the development number of lumbung desa and its capital in the form of rice and cash. The next section will be discussed about the village barn management which involved two kind of management models according to De Wolff and Mensman. This article also describes initial capital for the establishment of Lumbung Desa. The next section will be the advantages of this institution which has flexibility to survive when the Javanese people faced crisis due to economic depression of the 1930s.

\section{RESULTS AND DISCUSSION}

\section{The Existence and Development of Lumbung Desa}

Lumbung Desa existed in rural areas in Java since colonial era, especially in the beggining of XX century. Therefore, when the Dutch government implemented a program to address poverty issue in rural Java, thus the needed institution should be empowered, reformed, and developed. In response, the Dutch colonial government developed credit institutions at the village level. It was generally located in villages where rice could be grown as the main livelihood of rural people of Java. In many cases, villagers brought home their crops immediately when harvest season came because they had debt and were highly dependent on moneylenders and merchants. As results the crop price fell below expected rate of production cost. It was very detrimental, especially for farmers who felt their crops would be valued rapidly in harvesting season, it was happened when crops or rice already in traders (Stibbe, 1921).
This condition contributed significantly to the decrease of their income and this decreaed their well-being. In such a condition, the village barns functioned to serve farmers so that they could be independence from traders, middlemen, pengijon, and moneylenders that were very detrimental to them. In the bad socio-economic life of the indigenous people, loan sharks became the most benefited and wealthy. A brief illustration can be viewed in Prawiro Suwarno's life, it that referred as "the King of Pawn" during the depression (Amini, 2006). The village barn expected the farmers to take their time in selling their crops to traders or middlemen although they were in a great need for cash to pay their debts to moneylenders. Through Lumbung Desa, the price of rice could be stable throughout the year, so it had positive effects on food supply for the residents and the farmers' income. Furthermore, Lumbung Desa would allow farmers to work better without losing their capital (Djojohadikusumo, 1943).

Lumbung Desa benefitted for villagers, because the institution was come from, executed, and gave benefit to the villagers. It could be viewed on Lumbung Desa management. It was typically run with its own wealth gathered from villagers with certain criteria especially those who had rice fields. As property rights holders, the owners of rice fields were included villagers that given positions as financiers. In the active condition, the capital was in the forms of rice and cash which still owned by the institution. In addition to being deposited and loaned, it was for depreciation reserve, renovation, repair, and renew building. This reserve was paid as the capital to Bank Desa (village bank) deposited in a checking account of local banks and would be paid to the local people (Verslag van het Volkscredietwezen, 1911). This institution run by local communities at rural areas in the forms of rice or actual goods.

Lumbung Desa also had a function to stabilize rice price at farm level by preventing farmers from selling their rice right after it was (van Niel, 1984). It was an indigenous business established at their own expense. It was conducted by, and for villagers. Through Lumbung Desa, they took some portion of the harvest to fulfil their own needs and to anticipate difficulties that mightoccur. If they were not able to deposit rice in Lumbung Desa, the 
colonial government would provide zero-interest loan intended for farmers to purchase rice deposited in Lumbung Desa. When there was damage in Lumbung Desa, the government also provided assistance for rehabilitation and reconstruction. Its goals were achieved by government intervention. Lumbung Desa lent rice to the members who had in trouble, and it was realized by all the members. In this manner, the villagers were expected to be free of debt bodage from the usurer (Rinardi, 2011). In its development, when its capital increased because of interest accumulation, the founders would gain back their shares (the initial capital in the form of paddy or rice). After the rest of their shares became the communal property of villagers (Huls, 1904).

There were three varieties of Lumbung Desa, they were rice seedlings barns (Lumbung Bibit Desa), tax barns (Lumbung Pajak), barn cooperative (Koperasi Lumbung). One of the examples, Lumbung Bibit was originally implemented in around 1855. At the time, the colonial government in Batavia wanted to introduce in every village a communal rice barn, in order to provide all farmers with sufficient rice seedlings. Many peasant cultivators had no rice left when they should start preparing their sawahs, either because they had been obliged to sell their stock, or because the last harvest had been insufficient to feed a family for a whole year (Boomgaard, 1991). However, this instititution was questioned could provide a good quality of seeds as good as the rice that the farmes had handed in. The village head started to use the rice stock for their own commercial purposes.

During its development, the Dutch colonial government tried to develop Lumbung Desa as village credit institutions that were expected to help economic difficulties that were often faced by villagers. The colonial government encouraged indigenous administration to foster Lumbung Desa. With this policy, it developed rapidly during the first decade of the twentieth century. Almost every place in Java established it (MVO Resident Oostout, 1907). However, the establishment was mostly executed without taking into account the villagers credit needs in rice (MVO Resident Riensum, 1913). Within six years, the number of Lumbung Desa increased dramatically. In 1905, there were 5,301 Lumbung Desa and the number increased to 12,625 in 1911 , but in 1933 there were only 5.500 left due to so much resistance (Boomgaard, 1991). It shows that the government indeed actually encouraged the establishment of Lumbung Desa as credit institutions. The growth of Lumbung Desa can be seen in Figure 1 below.

\section{Figure 1. Number of Lumbung Desa during the} Period 1905-1940
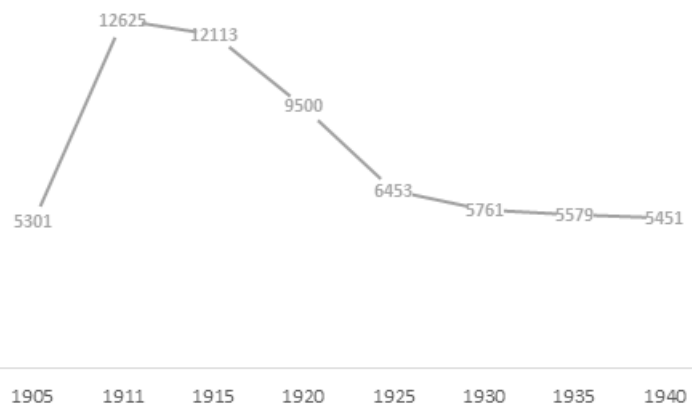

Source: Compiled from Koloniaal Verslag 1907 -

1917; Indisch Verslag 1931 and 1941; Statistisch Jaaroverzicht van Nederlandsch-Indië; and Statistical Pocket Book of Indonesia, 1941.

As a credit institution in village level, one of the advantages of Lumbung Desa was their ability to store and provide suitable credit both in cash and or rice. It unique and interesting, especially in relation with government's efforts to address problems faced by rural people in Java. In addition, the indicator shows that there was a trust among villagers in terms of the existence of Lumbung Desa as an institution to save and loan. Lumbung Desa had store rice from villagers with more than 120 thousand tonnes since 1907. Meanwhile, their savings in cash has certainly above f.6 million since 1919 (Rinardi, 2011).

A superlative achievement demonstrated the ability of Lumbung Desa to provide credit in rice occurred in the period of 1910 and 1911. At that time, it was able to collect 177,000 tonnes rice from rural areas and distributed as credit for debtors. After that period, their ability collect rice from the villagers was slowly declining. The situation was caused by changing interest of rural needs to loan money in cash compared than rice. At the same time, the number of Lumbung Desa 
continued to decrease, for example in 1911 there were 12.625 Lumbung Desa institution and in 1919 the number decreased to 9.974. Lumbung Desa tried to attract villagers in deposite and loan, the administrator prefered savings in cash rather than in rice. In this context, the development of the economic problems in rural Java became more complex caused the declining of Lumbung Desa as credit institution in village level.

Meanwhile, the performance of Lumbung Desa in raising fund from villagers were brilliant in 1931. At that time, Lumbung Desa collected fund ammounted $f 10.26$ million (van Laanen, 1980). It was the highest number that successfully achieved by Lumbung Desa that deposited by its members. The total number of rice and cash money that successfully collected can be viewed in Figure 2 below. It shows the development of the large quantity of rice had been collected from the rural areas of Java, while the Figure 3 shows the development of total money that successfully collected as capital. Both Figure 2 and 3, they are based on the same year, i.e. 1905-1940.

Figure 2. The number of rice that successfully collected by Lumbung Desa and distributed to the rurals as credit in 1905-1940 (in thousand tonnes)

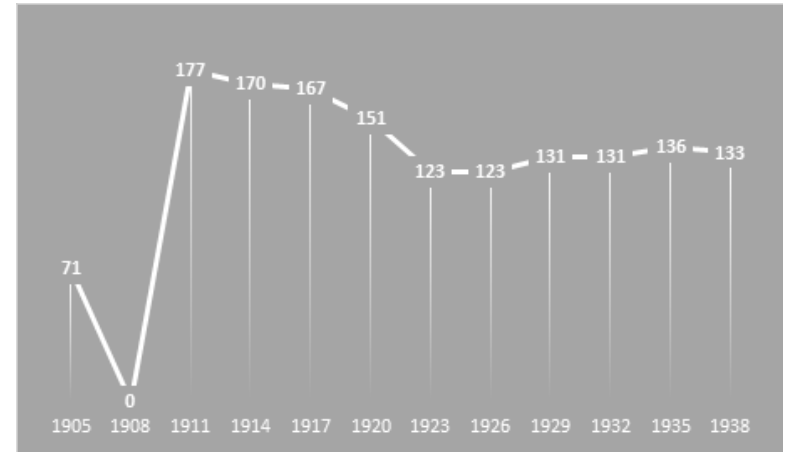

Sources: Processed from Van Laanen, 1980.

Lumbung Desa as microcredit institution had debtors that dominantly were villagers. In every year it has more than 1 million customers. They used it as a place to obtain loans, either in the form of rice or cash. In 1919 was recorded as the peak of success of Lumbung Desa based on the number of customers. There were 1.56 million customers in all operational areas. Lumbung Desa then had experienced on the declining of customer number, but the total customer was never less than 1 million people. Figure 4 illustrates those phenomenon.

Figure 3. Ammounts of money that successfully collected by Lumbung Desa as its capital in 19051940 (millions of guilders)

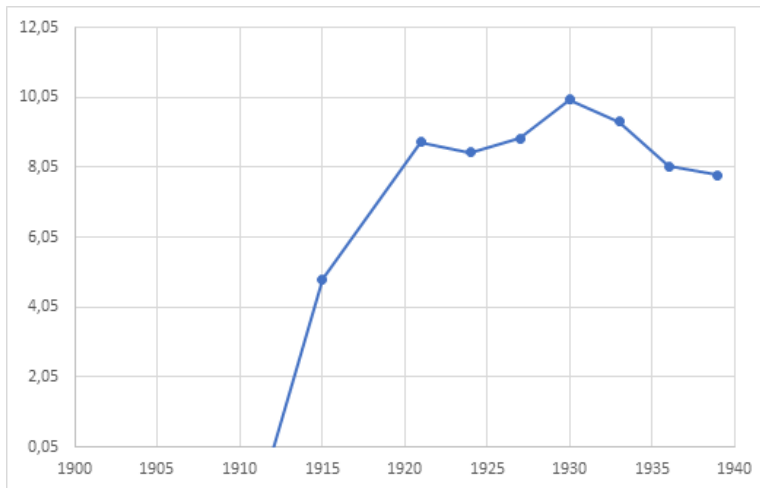

Sources: Compiled from Van Laanen, 1980.

Figure 4. Number of Debtors of Lumbung Desa 1915-1940 (Million People)

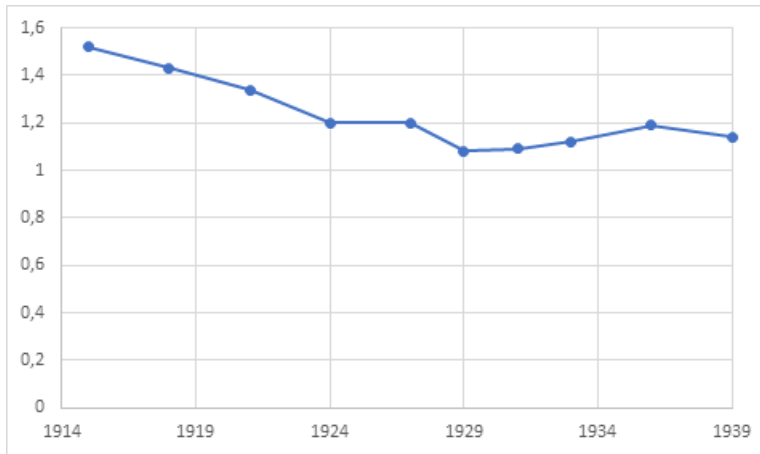

Source: Compiled from Van Laanen, 1980.

According of Figure 4, it is known that since 1920s customers of Lumbung Desa had decreased. The total customer was only million people, compared to the previous period that could reach approximately 1.3 million. The condition is caused by several factors. First, the customers of Lumbung Desa had transferred to village bank (Bank Desa). Second, the operational area were similar for both institutions that would become easier to transferred as Bank Desa's customer. Third, it was because of the complexity of economic development among rural communities. The increasing demand for cash had long been felt by rural community, it led 
the number of customeres were declined, as they shifted to Bank Desa. For the rurals, cash needs was more urgent than rice, so that they required to establish more of Bank Desa rather than Lumbung Desa.

\section{MANAGEMENT OF LUMBUNG DESA}

Lumbung Desa managed independently by village communities. The building of Lumbung Desa made from teak or illegal wood that came from trees along the village road and cemetery. The walls made from webbing bamboo with precarious in its roof. It was similar with traditional home by square niche in the wall. It usually established near village hall. It was kind of Javanese communal house guarded in a day and night.

The physical construction of Lumbung Desa financed by some donations from its shareholders, those who deposited a portion of their rice harvest and intended as initial capital. The donations would be in rice and money, if it was in rice, it should be similar with $f 0,2$ to $f 1,5$ in money applied to each shareholder establishment in Lumbung Desa. Moreover, in physical development process of Lumbung Desa executed by villagers communally. It managed by a committee consisted of a headman, clerk, Kayim, and two villagers who have wellreputable. They usually were appointed by Naib. The term of Naib needs to be shortly descibed as penghulu or modin.

The committee of Lumbung Desa was headed by a Naib. He had power to inspects or supervise committee member of Lumbung Desa. The two villagers who had pointed into committee members of Lumbung Desa selected by Naib that lived in the district. In the other hand, Naib was similar like "boss" of Kayim in religious personnel. They involved to supervise Lumbung Desa in district which its capital from villager alms (Zakat Fitrah). Naib was a leader of religious affairs to control and manage of Lumbung Desa. In that way, the existence of Naib could avoid mistakes in alms management of villagers. Naib was much involved to supervise management of Lumbung Desa.

Meanwhile the colonial government played an important role to maintain Lumbung Desa to be well-conducted and benefitted. They were similar as controller or the official of Bumiputera.
Meanwhile there were Wedana that in charged directly to supervise Lumbung Desa management. However, Naib also had duty to check rice availability in the barn and synchronized with the management book.

According to De Wolff, the bookkeeping of Lumbung made by village secretary. The model was conducted based on direction of regent and controller. So that, Lumbung Desa depended on the management roles and responsibilities of colonial bureaucracy. The bookkeeping of Lumbung Desa supervised under the committee members. According to their job description, a clerk of Lumbung Desa paid arround of the alms that was intended for village officials (Pamong Desa).

The committee members consisted of two ordinary residents who hold key to the barns, both were having their own keys. The opening of the barns door could only be done if witnessed by Kepala Desa. With this way, the Lumbung Desa had already implemented fairly and strict supervision. It locked with two types of keys, the barn doors could not be opened without permission from Kepala Desa. When the barn was opened, it could only be done with Kepala Desa as witness. It is expected that there would be no diversion or fraud in Lumbung Desa management because the opening barn door should be conducted with three people (Suharto, 1988).

Lumbung Desa according to De Wolff had some basic rules.

1. The rice amounts destined for Lumbung Desa was 4/10 of zakat. Rice then stored to the barns, and would be loaned to the villagers.

2. Each village should have their own barns that able to accommodate around 200 pikul of rice. In each farmer family would have storage space approximately $1 / 2$ pikul. If the amount of rice stored exceeded, the barn area could be enlarged into a maximum 5 pikul for each family. If it did not enough, then the ammount of rice that could not be accommodated, it would be sold and the money saved in treasury fund.

3. Rice in Lumbung Desa should be cultivated with the best treatment, so it might be used as seed. Therefore, the officials of Lumbung Desa was able to exchange some or all of 
rice in the barns with rice from the other barns. Through this way, the official could obtain the best seed of rice.

4. Credit from Lumbung Desa should be done based on weight unit and its weighed should be in definite scale.

5. The amount of credit obtained from Lumbung Desa were only five pikul and must be returned a month after harvest. If they proposed a maximum ammount, it would not be denied, unless villagers who had applied credit already meet requirements of Lumbung Desa.

6. The barns building should be sturdy with uniform model, its roofed should have a good door with a strong key. The keys hold by two residents who were the officials of the villagers who became the administrator of Lumbung Desa. The opening of the barns door should be witnessed by the village head.

7. The walls should be written as Lumbung Desa by a white chalk, so that would be easily recognized.

One of the areas that used De Wolff model was Cirebon. However, the people objected to set aside of their zakat as initial capital for Lumbung Desa. They assumed that the meaning and purpose of za kat designed for the poor. In this regard, the 1 and owners were willing to provide initial capit a 1 for Lumbung Desa. Besides that, there was d i fferent model of Lumbung Desa which diffe rent by De Wolff Model. It was known as Lumbung Desa Cirebon because it developed in Cirebon. Lumbung Desa Cirebon was also known as Lumbung Desa Mesman because it came from the name of Residen Cirebon who had introduced the $b$ arns management that totally different with De Wolff model. It had accepted and implemented by villagers in Cirebon. The Resident of Cirebon had modified the collecting ways of initial capital. Therefore, the model of Lumbung Desa in Cirebon was known as Mesman model. He fundamentally changed in management, the way of initial capital raising, supervision, and as well as revenue for the barn itself.

Lumbung Desa was thick of social characteristics, because it used to combat the debt bondage system (ijon) which considered to be detrimental among farmers. Therefore, the colonial government also provided various kinds of assistance either directly or indirectly to Lumbung Desa. The direct assistance was conducted by providing capital assistance, which could be used to buy rice from farmers. The government provided grants or subsidies to communities who wanted to establish Lumbung Desa. The government provided direct supplies of reserved rice or paddy for village barns. In addition, in some cases, such as in Karesidenan Surabaya, the resident even provided funds for the establishment of Lumbung Desa at Lamongan and Gresik. In another case, Resident Besuki had gave money of f. 200 to buy paddy from farmers for the initial capital of Lumbung Desa.

Another government aid or subsidy was to allow the residents to take timber in forest for the establishment of the barns building. In addition, if there was no building, so the residents were unable to collect initial capital to buy and store rice. Therefore, the government allowed the coffee warehouse as a temporary place to store rice before the building finished. The government also allowed the community to use former guard house as an emergency if there was still no barn (Koloniaal Verslag 1908: 57).

The Cirebon model management handled by a committee which set up and tasked to manage Lumbung Desa. The committee known as Mantri, they should check the barns which located in rural areas of Cirebon residency once a week (Stibbe, 1921). They paid from the barns that they have managed. At first, they got 10\% loan interest formed in rice (Anonymous, 1906). The 5\% of total loan interests was received by the barn's manager. Therefore, the duties and responsible of Mantri in the barns committee was reduced. It led their salary received was shrinking. They only received $5 \%$ of total loan interest of the barn (Cramer, 1929).

At first, the Cirebon models only lend to its members (who contributed initial capital for Lumbung Desa), but it did not applicable after initial capital restored. Thus, people who had not participated to submit rice as initial capital could loan in the barns. In operational, the barns charge its interest of $25 \%-50 \%$ of the borrowed rice. The barn management handed over to a committee 
manager: the village head, village secretary, two people as representative participants that consisted the owners of capital deposit in Lumbung Desa. The non-ofiicials were overrun in the committee that village officials did not abuse their authority (Suharto, 1988). Members of the committee paid for $10 \%$ of loans in form of rice (Anonymous, 1906). They paid with money, they would be responsible for Lumbung Desa management based on their ability and did not consider as additional burden (Cramer, 1929).

Several years later, the membership of the two non-official village was abolished and their authorities entirely done by village official. It was because they considered as useless and had no power to against village official domination in Lumbung Desa, especially from head of the village. Therefore, there were no opinions or suggestions submitted by members of the committee. They rarely gave information of their ammounts of credit borrowed from Lumbung Desa and did not want to get involved to collects credit that received by the debtor of Lumbung Desa. Their duties as key holder of the barns was not well executed. They usually leave the key of the barn to kuwu (Huls, 1904). In the other hand, village officials who were not members of the barns committee had been burdened additional tasks in Lumbung Desa without getting paid. Based on that condition, both of the role abolition was non-acceptable.

Lumbung Desa's committee in 1903 was replaced by the "Lumbung Gecommitteerden" or Lumbung Kometir. It established by the colonial government and appointed for conducting task to deal a collection of village managed about 10,000 pikul of rice. They were appointed as Kometir should have good reputable, similar dignity with head of the village, such as police or opas, prospective civil servants (intern), and others. That policy meant that they would be dare to face members of Lumbung Desa committee (Suharto, 1988).

\section{THE CAPITAL OF LUMBUNG DESA}

There were two models of Lumbung Desa, De Wolff and Mesman model. According to De Wolff model, Lumbung Desa emphasizes on the independence of villagers for collecting funds as initial capital. De Wolff views that villagers could use some of the alms (zakat) to collects and evolves into a cooperative association. The agency should notice of their own finance and initially helped the members in form of rice loan that were expected to develop into cash loan.

Rice loans helped farmers in lacking rice seeds condition or experiencing shortage during lean season. Farmers must return the amount of rice that had received plus a few percents cost of depreciation at harvest time.

Upon receiving loan from Lumbung Desa, farmers were required to submit an application to the village head than asked committee for opinion. Based on this rule, none of loan application could be approved without notification and approval of the barn committee members first. If there were any committee member stressing out the importance of certain application, the other committee members should report it to Naib who was inspector of Lumbung Desa management. If the problem deemed so important, then Naib could report it to Wedana.

The barns model of Mesman or Cirebon was different with De Wolff model, especially for collecting the initial capital. Mesman or Cirebon model obtained its initial capital from rice field owners then deposited as the shareholders of Lumbung Desa. They handed amounts of rice and deposit it accordance with their rice field coverage area. However, some of Kawedanan allowed people without rice field deposit their capital for establishment purposes of Lumbung Desa.

The ammounts determination and initial deposit time of each Lumbung Desa were different for each region. The amount of rice that should be paid for every member of Lumbung Desa as their initial capital adjusted for rice field areas owned by each member. In general, each member should deposit $1 / 4$ to 1 pikul (1 pikul almost similar with $60 \mathrm{~kg}$ ) for each rice field they have. Rice deposit could be done at once or gradually up to two years or longer. In some places the amounts and time deposit was not specified at all.

Loan interest rate between $25-50 \%$, and usually the Lumbung Desa had average loan interest 50\%. The $50 \%$ of loan interest was too high compared with amount of money received by farmers, but it was not too burdensome for them. Farmers usually borrowed rice from Lumbung Desa during growing 
or dry season. At that time, they were facing both rice seeds shortage and financial crisis to meet their needs. During the shortage, their rice would worth money as much as $f 3$ per pikul. If they had borrowed 2 pikul of rice from Lumbung Desa, they would receive money around $f 6$. During harvest season, they had to return 3 pikul of rice (consists of 2 pikul of loan plus 1 interest). In harvest time, they would have money as much as $f 2$ for 1 pikul of rice (Anonymous, 1906). Therefore, the 3 pikul as their payment would be worth much as $f 6$. Thus, the 50\% loan interest of Lumbung Desa Village Depository could not be considered as burdensome for farmers.

In Lumbung Desa, the $25-50 \%$ loan interest would be double rice supply and after a few years all initial capital could be returned to the members. In many cases, they could even donate their initial capital contribution to the Lumbung Desa. In this way, according to Mesman, Lumbung Desa can develop into a village-level credit institution and capable of giving loans to villagers especially rice farmers during plantation or in case of drought that resulted in famine.

Previously, the debtor of Mesman model was only villagers who had deposited their initial rice capital in the establishment of Lumbung Desa. In its development, after Lumbung Desa had been able to meet its needs, the initial capital was returned to shareholders and turned into a communal institution owned by villagers. Through this way, Lumbung Desa had its own rice that was profit from its management in storing rice as initial capital. The people who previously did not store rice as their initial capital in the barns, they could also be given a loan. The only condition was that they should be the local villagers, so that loans never be permitted to be given to people who lived in other village.

The stored rice could be returned to shareholders before Lumbung Desa has its own rice from profits if they had moved to another village. It could also be returned to shareholder's beneficiary if the shareholder dies. Under the applicable regulations, stored rice was returned to shareholders if they violate the rules, incurably ill, or a dismissed headman (Huls, 1904).

According to Mesman model, the maximum rice loan that could be borrowed by a villager was
5 pikul per year. In practice, villagers borrowed 1 pikul of rice in each time they applied for rice loan. They scheduled loan application to borrow, part one villager borrowed paddy for seed, and they us ed it to cultivate their rice filed, and part two remaining sacks for famine comes. The approval of credit laid under management committee's of Lumbung Desa.

The remaining rice in Lumbung Desa was traded every year. Some of incoming money was used to pay management cost and building maintenance. The rest of the money was deposited as reserved fund to an Afdelingsbank or community bank. In this way, indigenous population of rural Java had a debt-free Lumbung Desa building with sufficient rice supply inside. Moreover, villagers al so had saving account in Afdelingsbank as reserve fund (Koloniaal Verslag, 1914). If reserved fund of Lumbung Desa had increased amount higher than the needs, the rest of it would be deposited to village treasury and later it became village communal funds (Graff, Stibbe, 1918).

\section{FLEXIBILITY OF LUMBUNG DESA}

Historical facts show that Lumbung Desa was a village-level credit institution in a flexible nature due to its existence in the middle of rural area community where relational patterns were very personal and high level of trust. This distinct advantage allowed villagers as customers to store and take credit from the barns. Credit disbursement could be made any time and simultaneous with credit submission. Lumbung Desa as credit institution had flexible properties because it could transform into credit institution in accordance with villagers needs and it did not require either complicated mechanisms, procedures, or time consuming. The easy and fast principles in reality had become hallmark of Lumbung Desa mechanism that was developed during the 1930s. Lumbung Desa had evolved in accordance with villager's needs in rural Java, therefore, a large variety with various uses of Lumbung Desa could be found in Java. In its development, Lumbung Desa as village-level credit institution did not only serve rice credit but also monetary credit for the community. Some of them were in Surabaya, they used their spare money to be loaned to farmers with at least $1 \%$ interest/ month. It was widely 
used by credit debtors, i.e. farmers as agricultural credit because it was utilized for various plant cultivations (Verslag van het Volkscredietwezen, 1920).

Thus, there were two types of Lumbung Desa that different with other business units. First, it provided credit in rice and money; second, provided financial credit for the debtors, i.e. farmers in rural Java. Furthermore, based on the research conducted, there were several types of Lumbung Desa. First, Koperasi Lumbung or the barns union existed up to 1939 , there were 32 Koperasi Lumbung in Indonesia in that time, 13 out 32 were located in Indramayu precisely in Kawedanan Kandanghaur. Koperasi Lumbung was designed to eradicate moneylender or pengijon that mostly farmers used to lend money. In this case, farmers paid their loans to Koperasi Lumbung in rice. The differences of loans between Lumbung Desa and Koperasi Lumbung in the form of credits. Lumbung Desa gave loans in rice, while Koperasi Lumbung gave loans in cash, but both of them were similar in payments made in rice.

The second form of the barns was Lumbung Bibit (seed barns), spread in East Java residencies, i.e. Besuki and Madiun. The numbers reached hundreds of barns. Only in Besuki, there were more than 300 Lumbung Desa belonged to farmer's cooperative society under supervision of Agricultural Department. The Lumbung Bibit was also found in West Java, established by Department of Agriculture of West Java and aimed to increase the usage of best rice seeds. The seeds were normally selected by the members who stored rice in their own barns (Suharto, 1988).

The third type of the barn called Lumbung Pajak or tax barn. It actually was union institution founded and propagated by "Farm Pillars", an organization under Great Indonesia Party (Partai Indonesia Raya or Parindra). It was established because of the massive circulation of money to rural areas of Java. Taxes paid by farmers were derived from their rice trading money. It was help enough because farmers needed to temporarily hold their harvest until the price was in good condition, just like before harvest period, especially during dry season. Lumbung Pajak's role was to hold or piled up rice to be used to pay taxes. When rice price was back to normal, Lumbung Pajak would trade the rice. The proceeds would pay the member's tax and remaining rice would be returned to each member.

\section{CONCLUSION}

Lumbung Desa is village-level credit institutions providing credit in rice or cash. The credit institutions have traditionally existed in rural people of Java before the Dutch colonial government established Volkscredietwezen. Lumbung Desa based on character of villagers, they have personal social relationships with high level of confidence. It developed in rural area which their livelihood was to cultivate rice. In line with implementation of ethical policy, the colonial government was developed a credit in each rural area. It was expected to help farmers to fight against middlemen and moneylenders, so that their welfare and income would increase. By the government support, it developed rapidly during the early decades of the twentieth century. However, it then also stimulated the emergence with many problems that eventually made other barns closed or malfunctioned.

As credit institution at village level, Lumbung Desa could never be separated from the role of both government bureaucracy, Kawedanan and the village bureaucracy. It was executed on behalf to respect of villagers against their traditional leader. The credit institution existed and developed in funding relied on the villagers. Lumbung Desa collected rice and money from villagers who became the members. When Idhul Fitri comes, the management of Lumbung Desa would distribute net profit (profits after reduced by costs management) to the members. The ammount of profits distribution conducted according on how much rice or paid capital to the barn in the early days of harvest. Lumbung Desa existed and developed by that way in rural indigenous population of Java during colonial period.

Lumbung Desa lived and thrived because its flexibility and characterized by an easy and fast way, so it could adapt to fit the villager's needs as a customer. In the 1930s, there were three varieties of Lumbung Desa namely, Lumbung Pajak (tax barn), Lumbung Bibit (seedlings barn), and Koperasi Lumbung (barn union). Each type of the barns had their own advantages and developed according to the people needs. Based on that condition, Lumbung Desa could existed and thrived at least 
until beginning of the independence of Republic Indonesia.

\section{REFERENCES}

\section{Archives}

Central Bureau of Statistics, Statistical Pocketbook of Indonesia 1941, Jakarta: G. Kolff \& Co, 1947.

Indisch Verslag II: Statistisch Jaaroverzicht van Nederlandsch-Indië 1931-1941.

Koloniaal Verslag 1907; 1908; 1910; 1913; 1914, 1917.

MVO Koleksi Arsip Nasional Jakarta: Residen Priangan Oostout Tahun 1907, Rel No 2 Kode E; Residen Banten C.W.A. van Riensum 1913, Reel No. 1 Serie 1e.

Verslag van het Volkscredietwezen over het jaar, 1911, 1919, 1920.

\section{Books and Articles}

Amini, M. (2006). Aktivitas Ekonomi Orang Kalang di Kotagede Pada Masa Depresi 1930T, 18(2), $157-164$

Anonymous (1906). Inlandsch landbouwcrediet. De Indische Gids $I$.

Baudet, H., \& Brugmans, I. J. (1987). Politik Etis dan Revolusi Perjuangan. Jakarta: Yayasan Obor Indonesia.

Boomgaard, P. (1991). The Javanese village as a Cheshire cat: The Java debate against a European and Latin American background. The Journal of Peasant Studies, 18(2), 288-304. https://doi.org/10.1080/03066159108438453

Boomgaard, P. (2004). Anak Jajahan Belanda, Sejarah Sosial dan Ekonomi Jawa 1795-1880. Jakarta: Djambatan in cooperation with KITLV.

Cramer, J. C. (1929). Het volkscredietwesen in NederlandschIndiëAmsterdam:H.J.Paris.

Creutzberg, P. (1980). Changing Economy in Indonesia Vol. VI: Money and Banking 1816-1940 (Money and). The Hague: Martinus Nijhoff.

De Vries, E. (1987). Dinas-Dinas kemakmuran. In Politik Etis dan Revolusi. Jakarta: Yayasan Obor Indonesia.

Dixon, J. (1979). Production and Consumption of Cassava in Indonesia. Bulletin of Indonesian Economic Studies, 15(3), 83-106. https://doi. org/10.1080/00074917912331333601
Djojohadikusumo, S. (1943). Kredit Rakyat di Masa Depresi. Jakarta: LP3ES.

Graff, Stibbe, D. G. (1918). Encyclopedie van Nederlandsch Studie (Tweede del).

Henley, D. (2009). Credit and Debt in Indonesia, 8601930: From Peonage to Pawnshop, From Kongsi to Cooperative. (D. Henley \& P. Boomgaard, Eds.). Singapore: KITLV Press and ISEAS Singapore.

Huls, G. F. K. (1904). De Loemboeng Desa in de Residentie Cheribon. Tijdschrift van Nederlandsch Indie.

Kern, R. A. (1904). Landbouw Crediet op Java. De Indische Gids.

Knight, R. (2014). Rescued from the Myths of Time. Bijdragen Tot de Taal-, Land-En Volkenkunde / Journal of the Humanities and Social Sciences of Southeast Asia, 170(2-3), 313-341. https:// doi.org/10.1163/22134379-17002002

Rinardi, H. (2011). Kredit Untuk Rakyat: Kebijakan Kredit Kecil Perbankan Untuk Usaha Kecil dan Menengah 1904-199. Universitas Gadjah Mada.

Stibbe, D. G. (1921). Encyclopedie van Nederlandsch Indië. s-Gravenhage: Martinus Nijhoff.

Suharto, P. (1988). Sejarah Pendirian Bank Perkreditan Rakyat. Jakarta: Lembaga Pengembangan Perbankan Indonesia.

van der Eng, P. (2010). Market responses to climate stress: Rice in Java in the 1930s. Australian Economic History Review, 50(1), 62-79. https://doi. org/10.1111/j.1467-8446.2009.00272.x

van Niel, R. (1984). Munculnya Elit Modern Indonesia. Jakarta: Pustaka Jaya.

van Zanden, J. L., \& Marks, D. (2010). An Economic History of Indonesia, 1800-2010. London and New York: Routledge. 